UDC $577.112 .7+616-097+576.31$

\title{
Development of monoclonal antibody against protein Rictor, a component of the mTORC2 complex
}

\author{
O. M. Malanchuk \\ Institute of Molecular Biology and Genetics, NAS of Ukraine \\ 150, Akademika Zabolotnoho Str., Kyiv, Ukraine, 03680 \\ o.m.malanchuk@imbg.org.ua
}

\begin{abstract}
Aim. Rictor is a component of the protein complex mTORC2 that is activated by growth factors and regulates cell growth, survival and migration. Here, we describe the development of the Rictor specific monoclonal antibody and characterize its suitability for various immunological assays. Methods. Hybridoma technology has been used for the monoclonal antibody production. Immunization was carried out with the recombinant N-terminal fragment of human Rictor expressed in E. coli as a GST-tagged fusion protein. Results. Specific monoclonal antibody $(\mathrm{mAb})$ against Rictor has been developed. Conclusions. The generated mAb specifically recognizes the recombinant and endogenous Rictor and is suitable for Western blotting, immunoprecipitation, and immunofluorescence assays of mammalian cells. This $\mathrm{mAb}$ will be a useful tool for the investigations of a physiological role of Rictor as well as the function of the mTORC2 in general.
\end{abstract}

Ke y w or d s: Rictor, mTORC2, hybridoma technique, monoclonal antibody.

\section{Introduction}

The mammalian target of rapamycin (mTOR) signaling pathway is a central regulator of cell metabolism, growth, proliferation and survival and is deregulated in human diseases such as cancer, neurodegeneration, metabolic disorders and ageing [1]. The mTOR protein is a serine-threonine kinase and nucleates two distinct multi-protein complexes, mTOR complex 1 (mTORC1) and mTOR complex 2 (mTORC2), which regulate diverse cellular processes.

mTORC1 consists of the catalytic subunit mTOR, the regulatory-associated protein of mTOR (Raptor), mLST8 or mammalian lethal with Sec13 protein 8 (also known as G $\beta$ L), PRAS40 or proline rich Akt substrate $40 \mathrm{kDa}$, Deptor or DEP-domaincontaining mTOR-interacting protein, and the Tti1/ Tel2 complex [1]. The function of mTORC1 is tightly regulated by PI3-K/Akt and is sensitive to ra- pamycin [2]. Among the multiple functions of mTORC1, the best-characterized function is regulation of translation. It is performed via two downstream mediators, the eukaryotic initiation factor $4 \mathrm{E}$ (eIF4E)-binding protein 1 (4E-BP1) and the p70 ribosomal S6 kinase 1 (p70S6K1, S6K1). The latter demonstrates an aberrant expression in the various diseases or pathological states [3, 4].

mTORC2 contains mTOR, rapamycin-insensitive companion of mTOR (Rictor), mammalian stressactivated MAP-kinase interacting protein (mSIN1), and protein observed with Rictor 1 and 2 (Protor-1/2), mLST8, Deptor and the Tti/Tel2 complex [5-8]. The studies that define the mTORC2 cellular functions and signaling have lagged behind. mTORC2 is sensitive to the growth factors, not nutrients, and, in contrast to mTORC1, is associated with rapamycininsensitivity [5]. mTORC2 is also thought to modulate the growth factor signaling by phosphorylating the C-terminal hydrophobic motif of some AGC ki-

(C) 2015 O. M. Malanchuk; Published by the Institute of Molecular Biology and Genetics, NAS of Ukraine on behalf of Biopolymers and Cell.

This is an Open Access article distributed under the terms of the Creative Commons Attribution License (http://creativecommons.org/licenses/by/4.0/), which permits unrestricted reuse, distribution, and reproduction in any medium, provided the original work is properly cited 
nases such as Akt [9, 10], SGK [11], and PKC alpha $[12,13]$, and participates in the actin cytoskeleton rearrangements and cell survival but a detailed mechanism remains to be addressed.

So, taking into account a key role of the mTOR signalling cascade in the regulation of major multiple cellular functions, a more detailed understanding of its functioning and regulation will lead to new therapies for many human diseases. Furthermore, little is known about the precise role of unique components of mTORC1 (Raptor) and mTORC2 (Rictor) in cell signalling outside the complexes.

Therefore, the use of monoclonal antibodies to the key components of the complexes to distinguish them from each other could be a useful tool for the study of the above questions, particularly in the context of the localization and colocalization of both complexes in cells at different physiological and pathophysiological conditions. The lack of commercially available highly specific Rictor monoclonal antibodies (mAb), which could be used in all methods (Western-blot, immunoprecipitation and immunofluorescence assays), prompted us to develop this reagent. The recombinant GST-tagged N-terminal fragment of thec Rictor protein (GST-NtRictor) was used for the mice immunization and hybridoma screening procedure. Here, we report the development of Rictor $\mathrm{mAb}$ that efficiently recognizes recombinant and endogenous Rictor in all immunoassays.

\section{Materials and Methods}

\section{Purification of GST-NtRictor fusion protein}

The bacterial expression system has been used for production of human N-terminal Rictor fragment (1-100 aa) - GST-NtRictor fusion protein. Generated plasmid pET42a/NtRictor was transformed into E.coli Rosetta(DE3)pLysS and the expression of GST-NtRictor fused protein was induced with $1 \mathrm{mM}$ isopropyl-b-D(2)-thiogalactopyranoside (IPTG) for $3 \mathrm{~h}$ at $+37^{\circ} \mathrm{C}$. Affinity purification of GST- NtRictor was carried out under native conditions using Glutathione-Sepharose (Amersham, UK) as recommended by manufacturers. The quality of the purified recombinant protein (estimated molecular weight is about $46 \mathrm{kDa}$ ) was tested by sodium dodecyl sulfate-polyacrylamide gel electrophoresis (SDS-PAGE).

\section{Immunization}

Purified GST-NtRictor $(15 \mu \mathrm{g})$ in emulsified Freund's complete adjuvant (Sigma Chemical, St. Louis, MO) was injected intraperitoneally (i.p.) in 8-week-old female BALB/c mice every two weeks. When the titer of anti-Rictor antibody in the serum of immunized mouse reached $10^{-5}$, the hybridomas production was performed according to a standard protocol [14]. Three days before fusion, intraperitoneal immunization with $15 \mu \mathrm{g}$ of GST-NtRictor was carried out.

\section{Cell fusion}

Briefly, generation of $\mathrm{mAb}$ has been performed as described earlier [15]. Hybridomas were produced by fusing splenocytes of an immunized BALB/c mouse with SP2/0 myeloma cells using PEG (MW2000, Merck, Germany) in 1:10 ratio. Cells were grown in RPMI-1640 (Biochrom AG, Berlin, Germany) supplemented with $20 \% \mathrm{FBS}(\mathrm{v} / \mathrm{v})$, 1x hypoxanthineaminopterin-thymidine (HAT, Sigma). After 7 days, supernatants of growing hybridomas were screened with ELISA using purified GST-NtRictor. GST protein served as negative control. Positive for GSTNtRictor but not GST protein clones were selected and subcloned by limited serial dilution [14]. Supernatants of the growing hybridomas were used for further studies.

\section{ELISA assay}

Polystyrene 96-well plates were loaded with $100 \mu \mathrm{l}$ of GST-NtRictor $(0.3 \mu \mathrm{g} /$ well $)$ or GST $(0.3$ $\mu \mathrm{g} /$ well) for $2 \mathrm{~h}$ at $37{ }^{\circ} \mathrm{C}$. The plates were washed three times with PBS containing $0.1 \%$ Tween-20 (Sigma, USA). For blocking non-specific binding the plates were incubated with $2 \%$ bovine serum albumin (BSA) in PBS (pH 7.4) overnight at $4{ }^{\circ} \mathrm{C}$ (200 $\mu \mathrm{l} /$ well). Subsequently, the plates were loaded 
with $100 \mu \mathrm{l} /$ well aliquots of hybridoma supernatant and incubated for $1 \mathrm{~h}$ at $37^{\circ} \mathrm{C}$, serum from immunized mouse was used as positive control. After three times washing, $100 \mu \mathrm{l}$ of horseradish peroxidase (HRP)-conjugated goat anti-mouse IgG antibodies $(1: 5000 \mathrm{v} / \mathrm{v}$, Promega, USA) were added to each well following the incubation at $37^{\circ} \mathrm{C}$ for $1 \mathrm{~h}$. Plates were washed three times and substrate solution $\left(0.02 \% \mathrm{H}_{2} \mathrm{O}_{2}, 0.5 \mathrm{mg} / \mathrm{ml}\right.$ 2.2'-azino-bis(3-ethylbenzothiazoline-6-sulfonic acid) sodium salt (Sigma, USA) in $0.1 \mathrm{M}$ citrate-phosphate buffer (pH 5.8) was added to each well. After $15 \mathrm{~min}$ incubation at $37{ }^{\circ} \mathrm{C}$, the absorbance of each well was determined at $450-490 \mathrm{~nm}$ in ELISA reader.

\section{Positive clones selection by Western blot analysis}

Bacterially expressed GST-NtRictor recombinant protein was boiled in SDS gel-loading buffer (5X), resolved by $10 \%$ SDS/PAGE and electrotransferred to Immobilon-P membrane (Millipore, USA). The membrane was blocked by $0.5 \%$ gelatin in PBS for $1 \mathrm{~h}$ at room temperature (RT), washed with PBS containing $0.1 \%$ Tween 20 and divided into strips. Strips were incubated with either PBS (negative control), the polyclonal serum collected from GSTNtRictor immunized mouse (1:1000) (positive control), hybridoma supernatants from clones, or cell culture media alone (negative control) for $4 \mathrm{~h}$ at RT. After three times washing, HRP-conjugated goat anti-mouse $\lg$ (Promega, USA) was added to the strips and incubated for $1 \mathrm{~h}$ at RT. Strips were washed three times, and developed by ECL Western blotting reagent (Amersham, Sweden).

\section{Purification of $m A b$}

For monoclonal antibody ascitic fluid production, $\mathrm{BALB} / \mathrm{c}$ mice were injected with $0.5 \mathrm{ml}$ of Pristane and 10 days later inoculated with $5 \cdot 10^{6}$ of hybridoma cells [14]. The ascitic fluid was collected after 12 days. The fraction of immunoglobulins was precipitated from ascitic fluid with $50 \%$ ammonium sulfate, dialyzed overnight against phosphate-buffered saline (PBS) pH 7.4 and purified by affinity chroma- tography using Protein A-Sepharose CL-4B (Amersham, Sweden). The IgG fractions were pulled together and dialyzed against PBS. The aliquots of purified antibodies were stored at $-70{ }^{\circ} \mathrm{C}$.

\section{Collection of polyclonal serum}

The polyclonal serum has been collected from an immunized mouse by tail bleed before the hybridomas production was performed. The collected blood was incubated at $37^{\circ} \mathrm{C}$ for $1 \mathrm{~h}$ then transferred to $4{ }^{\circ} \mathrm{C}$ for $2 \mathrm{hrs}$, and after that spun down at $1500 \mathrm{rpm}$ for $15 \mathrm{~min}$ at $4{ }^{\circ} \mathrm{C}$. Serum was removed from cell pellet, diluted with equal volume of glycerol and stored at $-20^{\circ} \mathrm{C}$.

\section{Cell lines}

U373 (human glioblastoma), HEK293 (human embryonic kidney), MCF-7 (human breast adenocarcinoma), A549 (human lung carcinoma epithelial cells), HEPG2 (human liver carcinoma cell line), HeLa (human cervical cancer cells), Jurkat (human acute $\mathrm{T}$ cell leukemia) and Primary human fibroblasts were grown in DMEM medium supplemented with $10 \%(\mathrm{v} / \mathrm{v})$ fetal calf serum (FCS) and $2 \mathrm{mM}$ L-glutamine.

\section{Immunoblotting of cell lysates}

U373, HEK293, MCF-7, A549, HEPG2, HeLa, Jurkat and Primary human fibroblasts were lysed with lysis buffer (50 mM Tris-HCI, pH 7.5, $150 \mathrm{mM}$ $\mathrm{NaCl}, 1$ \% NP 40, $50 \mathrm{mM}$ NaF, 2 mM EDTA, $10 \mathrm{mM}$ $\mathrm{Na}_{4} \mathrm{P}_{2} \mathrm{O}_{7}$ ) containing the protease inhibitors cocktail (Roche Molecular Diagnostics, France) and spun down at $10000 \mathrm{rpm}$ for $10 \mathrm{~min}$. Protein concentration in supernatant was estimated by BSA assay (Pierce, USA), and equal amounts of protein $(50 \mu \mathrm{g})$ were resolved in SDS-PAGE. Gels were transferred to polyvinylidene difluoride (PVDF) membrane (Millipore, USA). The membrane was blocked with $0.5 \%$ gelatine in PBS containing $0.05 \%$ Tween-20 (PBST) for $1 \mathrm{~h}$ at RT and incubated overnight $(\mathrm{o} / \mathrm{n})$ with purified antibodies of positive clones at $4{ }^{\circ} \mathrm{C}$. After washing with PBS-T, membrane was stained with HRPconjugated goat anti-mouse $\lg \mathrm{G}$ (Promega, USA) 
during $1 \mathrm{~h}$ at RT. As a loading control, mouse antiactin antibody was used (Sigma, USA). Finaly, membranes were developed by ECL Western blotting reagent (Amersham, Sweden).

\section{Immunoprecipitation}

The antibodies obtained from clone D4 $(1 \mu \mathrm{g})$ were incubated with $25 \mu \mathrm{l}$ of $50 \%$ suspension of Protein A-Sepharose CL-4B (Amersham, Sweden) for $2 \mathrm{~h}$ at $4{ }^{\circ} \mathrm{C}$. Then, the beads were washed three times in lysis buffer and the lysate (500 $\mu \mathrm{g}$ of protein) from HEK 293 cell line was added. After incubation o/n at $4^{\circ} \mathrm{C}$, beads were washed four times with $1 \mathrm{ml}$ of lysis buffer. Immune complexes were removed from beads by boiling in SDS gel-loading buffer (5X) and separated by SDS-PAGE. Resolved proteins were visualized by Coomassie staining or transferred onto PVDF membrane for Western blotting.

\section{Immunofluorescence analysis}

MCF-7 cells cultured on glass slides were fixed with methanol for $5 \mathrm{~min}$ at room temperature. Thereafter, the cells were treated with $0.2 \%$ Triton X100 in PBS for $15 \mathrm{~min}$. The samples were incubated for $30 \mathrm{~min}$ in $10 \mathrm{mM}$ cupric sulphate in $50 \mathrm{mM}$ ammonium acetate, $\mathrm{pH}$ 5.0, to eliminate autofluorescence. Non-specific binding was blocked after incubation with $10 \%$ FCS for $30 \mathrm{~min}$. Antibodies obtained from clone D4 (anti-Rictor) were used in the concentration of $1 \mu \mathrm{g} / \mathrm{ml}$. The secondary FITC conjugated anti-mouse antibodies were applied in dilution 1:100 (Jackson ImmunoResearch, West Grove, PA, USA). As negative control, MCF7 cells were incubated with secondary FITC conjugated anti-mouse antibodies alone. Nuclei were counterstained with PI. All microscopy studies were performed using Leica DM1000 light microscope (Leica, Wetzlar, Germany).

\section{Results and Discussion}

Despite the progress toward understanding the control mechanism of both anabolic and catabolic processes by mTOR via mTORC1, the function and regulation of mTORC 2 currently are not well understood. We were interested in elucidating the mo- lecular mechanisms of functioning of the Rictor protein independently and mTORC2 in general as well as in studying the localization and colocalization of both complexes in cells in different physiological and pathophysiological conditions. In the course of this study, we noticed the lack of commercially available highly specific Rictor monoclonal antibodies, which would recognize efficiently the endogenous Rictor in all immunoassays (Westernblot,Immunoprecipitation and Immunofluorescence). Therefore we decided to develop the monoclonal antibodies that meet all mentioned requirements.

Therefore, at the first stage, we used the bacterial expression system to produce the recombinant N-terminal peptide of human Rictor for the mouse immunization and hybridoma screening. GSTNtRictor was highly expressed upon the IPTG induction and shown to be soluble under the native conditions. For the GST-NtRictor fusion protein purification, the Glutathione-Sepharose affinity chromatography was used (Fig. 1).

At the second stage, we maintained the standard scheme of immunization, boosting animals every 2 weeks. The titer of anti-Rictor antibodies in the serum of immunized mice was nearly $10^{-5}$ after the third immunization. The immune spleen cells were

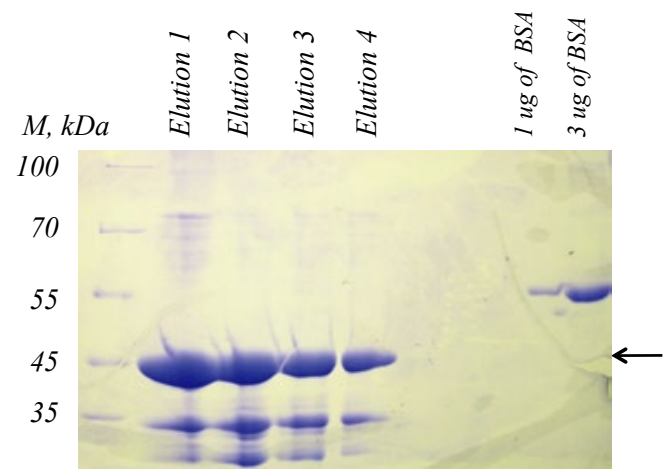

Fig. 1. Affinity purification of recombinant GST-NtRictor and analysis by SDS-PAGE. Affinity purification of GST-NtRictor protein on GST-sepharose under native conditions. The GSTNtRictor expressing cells were incubated with the GST-sepharose as described in Material and Methods. After elution [the] obtained fractions were resolved by SDS-PAGE and Coomassie stained. The position of recombinant GST-NtRictor is indicated by arrowv 
fused with the myeloma cells Sp2/0 using PEG. The resulting hybridoma cells were selected in HAT medium and tested for the production of the anti-Rictor antibodies in ELISA. GST protein was used as a negative control. We selected 60 hybridoma clones positive for GST-NtRictor but not for the GST protein in the first round of screening. For the clones selected the second ELISA screening was performed three days later that confirmed the GST-NtRictor specificity for 11 clones.

Then the supernatants from 11 positive clones were further tested by Western blotting using GSTNtRictor fusion protein. In this analysis, we confirmed the Rictor recognition by eleven clones (Fig. 2). Six positive clones, which showed the highest immune reactivity (E5/6, G2/6, B4/6, D4/2, D4/7 and $\mathrm{C} 7 / 5$ ) were subcloned twice using limiting dilution method. Subcloned hybridomas were tested by ELISA and Western blotting and showed specific recognition of recombinant GST-NtRictor. The obtained results clearly indicated that only one $\mathrm{mAB}$, which designated as D4, recognized a protein at the level corresponding to GST-NtRictor in Western blot analysis using GST-NtRictor as antigen (data not shown).

Next, to determine whether the selected D4 mAb can recognize the endogenous Rictor, we tested their specificity in Western blotting on the one hand using cell lysates from different cell lines and in immunoprecipitation assay using a total lysate of the HEK

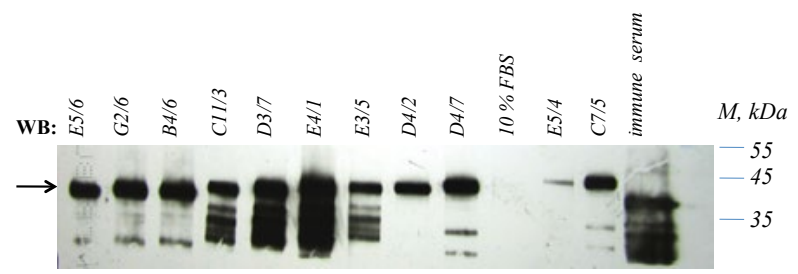

Fig. 2. Western-blot analysis of hybridoma supernatants from different clones with recombinant GST-NtRictor.

Recombinant GST-NtRictor was separated in numerous lanes by SDS-PAGE and transferred to PVDF membrane. The strips of membranes, corresponding to one lane were immunoblotted with hybridoma media from Rictor positive supernatants. AntiRictor polyclonal serum and 10\% FBS in cell culture media were used as positive and negative control, respectively.

The position of GST-NtRictor protein is indicated by arrow
293 cell line on the other hand. We found that in Western-blot D4 mAb recognizes a protein of approximately $190 \mathrm{kDa}$ in all cell lines (Fig. 3). The molecular weight of an immnoreactive band corresponds to the canonical isoform of Rictor. Taking into account that as an antigen for the immunization and hybridoma screening we used human Rictor peptide, at the next stage we analyzed the cross reactivity of the generated D4 mAb with Rictor from other mammals. Western blot analysis of cell lysates from the cell lines of different origin showed the cross-reactivity of mAb produced by D4 clone with Rictor from mouse, rat, and human (data not shown). Furthermore, Fig. 4 shows the ability of selected $\mathrm{mAb}$ to immunoprecipitate specifically Rictor from HEK 293 cells.

Finally, we examined D4 mAb in immunofluorescence assay using MCF7 cell line. The analysis was performed as described in Materials and methods. As shown in Fig 5, D4 mAb revealed mostly a diffuse, cytoplasmic distribution of the endogenous Rictor and minor nuclear localization (Fig. 5). As a negative control, the MCF7 cells were incubated with the secondary FITC conjugated anti-mouse an-

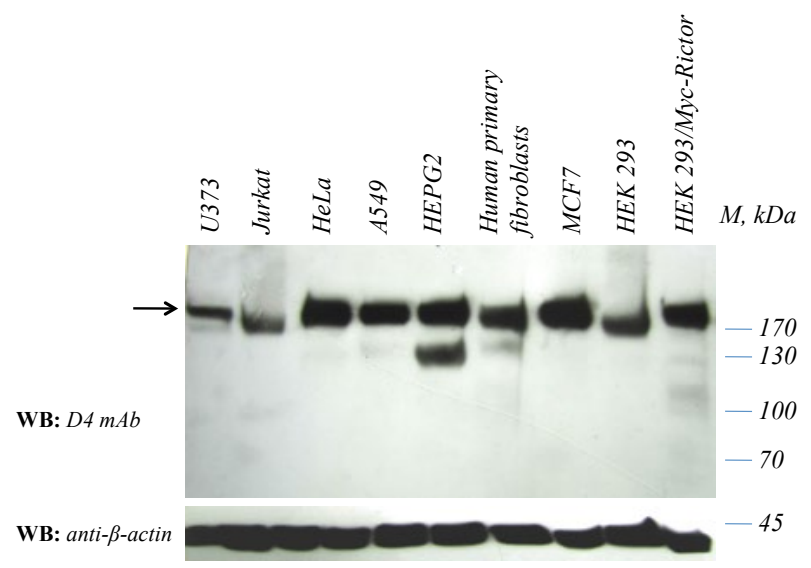

Fig. 3. Western-blot analysis of monoclonal antibody D4 using panel of cell lines.

Endogenous Rictor is specifically recognized by D4 mAb in Western blotting of panel of mammalian cell lines. Total cell lysates were separated by SDS-PAGE and immunoblotted with D4 mAb. HEK293 cell line transiently transfected with pRK5/ Myc-Rictor plasmid was used as positive control.

The position of Rictor is indicated by arrow 


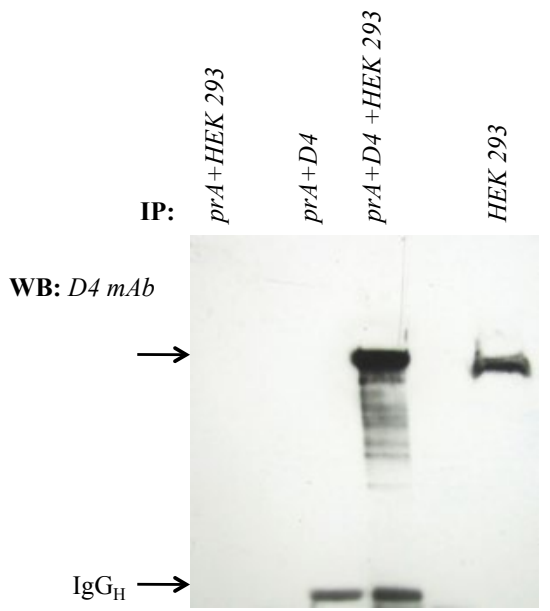

Fig. 4. Western-blot analysis of application of monoclonal antibody A4/1 in immunoprecipitation assay (A and B).

Total cell lysates of HEK293 cells were incubated with Protein A-Sepharose containing IgGs from D4 mAb. After extensive washing of beads with cell lysis buffer, specifically associated proteins were resolved by SDS-PAGE and immunoblotted with D4 mAb. The Protein A-Sepharose pre-incubated with lysate from HEK 293 cells alone served as a negative control.

The position of Rictor is indicated by arrow

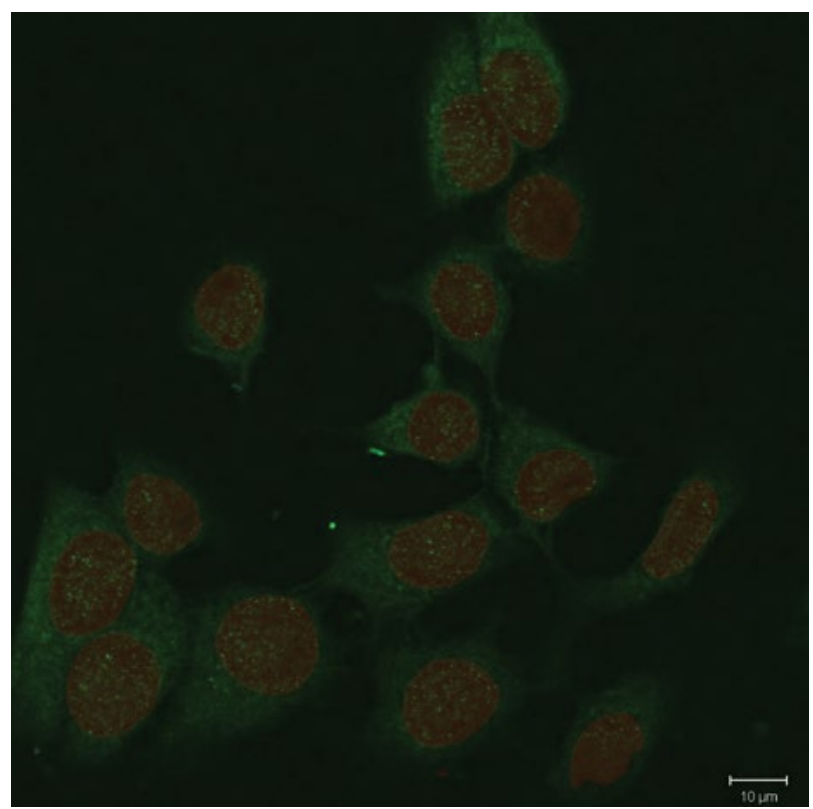

Fig. 5. Detection of Rictor localization in the human breast adenocarcinoma MCF-7 cell line.

MCF7 cells growing in $10 \%$ serum were stained with the Rictor (D4 mAb) antibodies. Nuclei were counterstained with PI tibodies alone (data not shown). There are longstanding speculations about subcellular localization of mTORC2 and Rictor as a part of complex. According to the most important reports that investigate the TORC2 and mTORC2 localization using confocal imaging and not only (subcellular fractionation and immuno-EM), mTORC2 has consistently been identified in proximity to mitochondria, the ER (endoplasmic reticulum) and MAM (mitochondriaassociated ER membranes) [16-19]. Other studies suggest that mTORC2 is in the nucleus (a nuclear function for mTORC2 is so far unknown) or at the plasma membrane (suggests that only a minor fraction of mTORC2 is at the plasma membrane) [20 28]. Taking together, the subcellular localization of Rictor, detected with $\mathrm{D} 4 \mathrm{mAb}$, correlates with the previously published immunofluorescence analysis data [16-28].

In summary, this study describes the production of monoclonal antibody using hybridoma technique, which specifically recognizes mammalian protein Rictor. The generated $\mathrm{mAb}$ could be suitable for various immunoassays, including ELISA, Western blotting, immunoprecipitation and immunofluorescence assays. Application of the presented new antibodies especially in confocal microscopy may be helpful in testing the co-localization of the investigated antigen with other proteins. Furthermore, this $\mathrm{mAb}$ could be a useful tool in study of both Rictorand mTORC2-mediated signalling under the normal and different pathophysiological conditions.

\section{Acknowledgements}

I thank Prof. Filonenko V. V. (Dep. of Cell Signalling, Institute of molecular biology and genetics, NAS of Ukraine) for valuable comments and critical review of the manuscript.

\section{REFERENCES}

1. Laplante M, Sabatini DM. mTOR signaling in growth control and disease. Cell. 2012;149(2):274-93.

2. Shimobayashi $M$, Hall $M N$. Making new contacts: the mTOR network in metabolism and signalling crosstalk. Nat Rev Mol Cell Biol. 2014;15(3):155-62. 
Development of monoclonal antibody against protein Rictor, a component of the mTORC2 complex

3. Filonenko VV, Tytarenko R, Azatjan SK, Savinska LO, Gaydar YA, Gout IT, Usenko VS, Lyzogubov VV. Immunohistochemical analysis of S6K1 and S6K2 localization in human breast tumors. Exp Oncol. 2004;26(4):294-9.

4. Lyzogubov V, Khozhaenko Y, Usenko V, Antonjuk S, Ovcharenko $G$, Tikhonkova I, Filonenko $V$. Immunohistochemical analysis of Ki-67, PCNA and S6K1/2 expression in human breast cancer. Exp Oncol. 2005;27(2):141-4.

5. Sarbassov DD, Ali SM, Kim DH, Guertin DA, Latek RR, Erdjument-Bromage H, Tempst P, Sabatini DM. Rictor, a novel binding partner of mTOR, defines a rapamycin-insensitive and raptor-independent pathway that regulates the cytoskeleton. Curr Biol. 2004;14(14):1296-302.

6. Pearce LR, Huang X, Boudeau J, Pawłowski R, Wullschleger S, Deak M, Ibrahim AF, Gourlay R, Magnuson $M A$, Alessi DR. Identification of Protor as a novel Rictorbinding component of mTOR complex-2. Biochem J. 2007; 405(3):513-22.

7. Woo SY, Kim DH, Jun CB, Kim YM, Haar EV, Lee SI, Hegg $J W$, Bandhakavi S, Griffin TJ, Kim DH. PRR5, a novel component of mTOR complex 2, regulates platelet-derived growth factor receptor beta expression and signaling. $J$ Biol Chem. 2007;282(35):25604-12.

8. Kaizuka T, Hara T, Oshiro N, Kikkawa U, Yonezawa K, Takehana K, Iemura S, Natsume T, Mizushima N. Ttil and Tel2 are critical factors in mammalian target of rapamycin complex assembly. J Biol Chem. 2010;285(26):20109-16.

9. Sarbassov DD, Guertin DA, Ali SM, Sabatini DM. Phosphorylation and regulation of Akt/PKB by the rictor-mTOR complex. Science. 2005;307(5712):1098-101.

10. Jacinto E, Loewith R, Schmidt A, Lin S, Rüegg MA, Hall A, Hall MN. Mammalian TOR complex 2 controls the actin cytoskeleton and is rapamycin insensitive. Nat Cell Biol. 2004;6(11):1122-8.

11. García-Martínez JM, Alessi DR. mTOR complex 2 (mTORC2) controls hydrophobic motif phosphorylation and activation of serum- and glucocorticoid-induced protein kinase 1 (SGK1). Biochem J. 2008;416(3):375-85.

12. Facchinetti $V$, Ouyang $W$, Wei $H$, Soto $N$, Lazorchak $A$, Gould C, Lowry C, Newton AC, Mao Y, Miao RQ, Sessa $W C$, Qin J, Zhang P, Su B, Jacinto E. The mammalian target of rapamycin complex 2 controls folding and stability of Akt and protein kinase C. EMBO J. 2008;27(14):1932-43.

13. Ikenoue T, Inoki K, Yang Q, Zhou X, Guan KL. Essential function of TORC2 in PKC and Akt turn motif phosphorylation, maturation and signalling. EMBO J. 2008;27(14):1919-31.

14. Harlow E., Lane D. Using antibodies: A laboratory manual. New York: Cold Spring Harbor Lab. press, 1998. 495 p.

15. Hurrell J. G. R. Monoclonal hybridoma antibodies: Techniques and application. Boca Raton: CRC press, 1982. $231 \mathrm{p}$.

16. Boulbés DR, Shaiken T, Sarbassov dos D. Endoplasmic reticulum is a main localization site of mTORC2. Biochem Biophys Res Commun. 2011;413(1):46-52.
17. Desai BN, Myers BR, Schreiber SL. FKBP12-rapamycinassociated protein associates with mitochondria and senses osmotic stress via mitochondrial dysfunction. Proc Natl Acad Sci US A. 2002;99(7):4319-24.

18. Betz C, Stracka D, Prescianotto-Baschong C, Frieden M, Demaurex N, Hall MN. mTOR complex 2-Akt signaling at mitochondria-associated endoplasmic reticulum membranes (MAM) regulates mitochondrial physiology. Proc Natl Acad Sci U S A. 2013;110(31):12526-34.

19. Poston CN, Krishnan SC, Bazemore-Walker CR. In-depth proteomic analysis of mammalian mitochondria-associated membranes (MAM). J Proteomics. 2013;79:219-30.

20. Rosner M, Hengstschläger M. Cytoplasmic/nuclear localization of tuberin in different cell lines. Amino Acids. 2007;33(4):575-9.

21. Rosner $M$, Hengstschläger $M$. Cytoplasmic and nuclear distribution of the protein complexes mTORC1 and mTORC2: rapamycin triggers dephosphorylation and delocalization of the mTORC2 components rictor and $\sin 1$. Hum Mol Genet. 2008;17(19):2934-48.

22. Rosner M, Hengstschläger M. mTOR protein localization is cell cycle-regulated. Cell Cycle. 2011;10(20):3608-10.

23. Rosner M, Hengstschläger M. Detection of cytoplasmic and nuclear functions of mTOR by fractionation. Methods Mol Biol. 2012;821:105-24.

24. Kunz J, Schneider U, Howald I, Schmidt A, Hall MN. HEAT repeats mediate plasma membrane localization of Tor $2 \mathrm{p}$ in yeast. J Biol Chem. 2000;275(47):37011-20.

25. Wedaman KP, Reinke A, Anderson S, Yates J 3rd, McCaffery $J M$, Powers T. Tor kinases are in distinct membrane-associated protein complexes in Saccharomyces cerevisiae. Mol Biol Cell. 2003;14(3):1204-20.

26. Aronova $S$, Wedaman $K$, Anderson $S$, Yates $J 3 r d$, Powers $T$. Probing the membrane environment of the TOR kinases reveals functional interactions between TORC1, actin, and membrane trafficking in Saccharomyces cerevisiae. Mol Biol Cell. 2007;18(8):2779-94.

27. Sturgill TW, Cohen A, Diefenbacher M, Trautwein M, Martin DE, Hall MN. TOR1 and TOR2 have distinct locations in live cells. Eukaryot Cell. 2008;7(10):1819-30.

28. Berchtold D, Walther TC. TORC2 plasma membrane localization is essential for cell viability and restricted to a distinct domain. Mol Biol Cell. 2009;20(5):1565-75.

\section{Отримання моноклональних антитіл до компонента комплекса mTORC2 білка Rictor}

\section{О. М. Маланчук}

Ціль. Rictor $є$ унікальним компонентом білкового комплекса mTORC2, що активується ростовими факторами та регулює ріст клітин, виживання та міграцію. В даній статті описано процедуру отримання моноклональних антитіл, специфічних до Rictor, а також особливості їх використання у різноманітних 
імунологічних методах аналізу. Методи. Для отримання моноклональних антитіл було використано гібридомну технологію. Імунізацію проводили рекомбінантним GST-таг злитим $\mathrm{N}$-термінальним фрагментом Rictor, синтезованим в E. coli. Результати. Отримано специфічні моноклональні антитіла проти Rictor. Висновки. Отримані моноклональні антитіла специфічно розпізнають рекомбінантний та ендогенний Rictor в Вестерн-блот аналізі, імунопреципітації та імунофлюорисценції клітин ссавців, та можуть бути використані як необхідний інстумент досліджень при вивченні як індивідуальної фізіологічної ролі Rictor в клітині, так і в складі комплекса mTORC2 в цілому.

Кл юч о в і с л о в а: Rictor, mTORC2, гібридомна технологія, моноклональні антитіла.

\section{Получение моноклональных антител к компоненту комплекса mTORC2 белку Rictor}

\section{О. Н. Маланчук}

Цель. Rictor является уникальным компонентом белкового комплекса mTORC2, который активируется ростовыми факто- рами и регулирует рост клеток, выживание и миграцию. В данной статье описано процедуру получения моноклональных антител, специфичных к Rictor, а также особенности их использования в различных иммунологических методах анализа. Методы. Для получения моноклональных антител была использована гибридомная технология. Иммунизацию проводили рекомбинантным GST-таг слитым N-терминальным фрагментом Rictor, синтезированном в E.coli. Результаты. Получены специфические моноклональные антитела против Rictor. Выводы. Полученные моноклональные антитела специфично распознают рекомбинантный и эндогенный Rictor в Вестернблот анализе, иммунопреципитации и иммунофлюорисценции клеток млекопитающих, и могут быть использованы как необходимый инстумент исследований при изучении как индивидуальной физиологической роли Rictor a в клетке, так и в coставе комплекса mTORC2 в целом.

Кл юч ев ы е сл ов а: Rictor, mTORC2, гибридомная технология, моноклональные антитела.

Received 20.07.2015 